\begin{tabular}{|c|c|c|}
\hline $\begin{array}{c}\text { Record of Microeuraphia depressa } \\
\text { (Thecostraca: Balanomorpha: } \\
\text { Chthamalidae) on the Romanian } \\
\text { Black Sea Shelf }\end{array}$ & $\begin{array}{c}\text { "Cercetări Marine“6 } \\
\text { Issue no. 51 }\end{array}$ & \\
$\begin{array}{c}\text { Pages 188 - 192 } \\
\text { (Adrian Filimon, Valeria Abaza) }\end{array}$ & $\mathbf{2 0 2 1}$ \\
\hline \multicolumn{2}{|c|}{ DOI:10.55268/CM.2021.51.188 } \\
\hline
\end{tabular}

\title{
Short communication: RECORD OF MICROEURAPHIA DEPRESSA (THECOSTRACA: BALANOMORPHA: CHTHAMALIDAE) ON THE ROMANIAN BLACK SEA SHELF
}

\author{
Adrian Filimon, Valeria Abaza \\ ${ }^{1}$ National Institute for Marine Research and Development “Grigore Antipa”, \\ 300 Mamaia Blvd., 900581, Constanta, Romania, \\ E-mail: afilimon@alpha.rmri.ro
}

\begin{abstract}
Acorn barnacle Microeuraphia depressa (Poli, 1791) (Thecostraca: Balanomorpha: Chthamalidae) was recently found (March 2021), in the Romanian Black Sea. Compact populations were found during a rapid biofouling survey in Constanta harbour on artificial hard substrata from the waterline up to $20 \mathrm{~cm}$. Some hypothesis regarding actual and historical presence in the Romanian waters are discussed.
\end{abstract}

Key-Words: Microeuraphia depressa, barnacle, Constanta harbour, Romania, Black Sea.

\section{AIMS AND BACKGROUND}

The paper aims to point out the presence of acorn barnacle Microeuraphia depressa (syn. Chthamalus depressus), on the Romanian Black Sea shelf.

Poli (1791) described for the first time two barnacle species as Lepas depressa and Lepas stellata. Later on, Ranzani (1818) established the genus Chthamalus. Darwin (1854) considered Poli`s species as varieties of Chthamalus stellatus. Southward (1964) reverted the two varieties to specific rank and set up the new species C. depressus. Newman \& Ross (1976) have placed it into the genus Euraphia resulting the species name Euraphia depressa. Currently, the accepted species name is Microeuraphia depressa (WoRMS, 2021).

M. depressa is distributed in the eastern Atlantic, Mediterranean, the Adriatic and the Black Sea (Poltarukha, 2006; Igić, 2007; Linetskii et al., 2020). 
At the Romanian Black Sea shore, four species of acorn barnacle were reported: Amphibalanus improvisus (the most common), Amphibalanus eburneus, C. stellatus and Amphibalanus amphitrite (Băcescu et al., 1971; Preda et al., 2012). After the 1954 frost, C. stellatus virtually disappeared from the Romanian Black Sea coast (Bacescu et al., 1971).

\section{EXPERIMENTAL}

During a rapid biofouling communities assessment survey held in Constanta harbour (44.088414 ${ }^{\circ} \mathrm{N}$; $28.689356^{\circ} \mathrm{E}$ ) in March 2021, a different acorn barnacle species was observed. A few specimens were collected, stored in $96 \%$ ethanol and identified according to specialist taxonomic guides (Relini, 1980; Poltarukha, 2006). The carino-rostral distance was measured using a caliper with 0.1-mm precision. After identification, we extended our research to other Romanian harbours but no individual was found. Field observations (e.g. habitat preference, habitat occupancy, accompanying species) were also carried out. Whole individuals and body parts used for taxonomical identification were deposited in the author's collection.

\section{RESULTS AND DISCUSSIONS}

The historical presence of $M$. depressa on the Romanian Black Sea shelf remains uncertain. As mentioned before, for a long time M. depressa (i.e. C. depressus) was considered a variety of $C$. stellatus. Zernov never mentioned it in his works, but $M$. depressa was later found in his re-examined samples from the Black Sea (Southward, 1964). In Romania, C. stellatus was common before 1954 (Borcea, 1931; 1937; Antipa, 1941). Therefore, we consider that the species could have been present at the Romanian littoral and misidentified as C. stellatus. Unfortunately, without historical samples, the assumption cannot be verified.

Currently, we found monospecific and gregarious populations of $M$. depress $a$ on the artificial hard substrata (concrete) from above the waterline to over $20 \mathrm{~cm}$ (i.e. corresponding to supralittoral zone). Two morphological forms (varieties) can be distinguished: variety from the surf zone and the sheltered variety (hypobiotic form or typical form) (Utinomi, 1959; Kensler et al., 1965). In Constanta harbour it was found in sheltered, secluded places, never on exposed surfaces (Fig. 1). Due to low waves activity inside the harbour, $M$. depressa populations are moistened whenever big cargo ships enter or leave the harbour and during the storms. The populated substrate is never completely dry.

Solitary individuals scattered over the substrate on the undersides of the stones were also found. Accompanying barnacle was Amphibalanus improvisus. Dr. M. Skolka also stated that some M. depressa individuals were 
found underside of the stones at the Romanian littoral, between 2 Mai and Vama Veche localities in the same period (personal communication, June 2021).

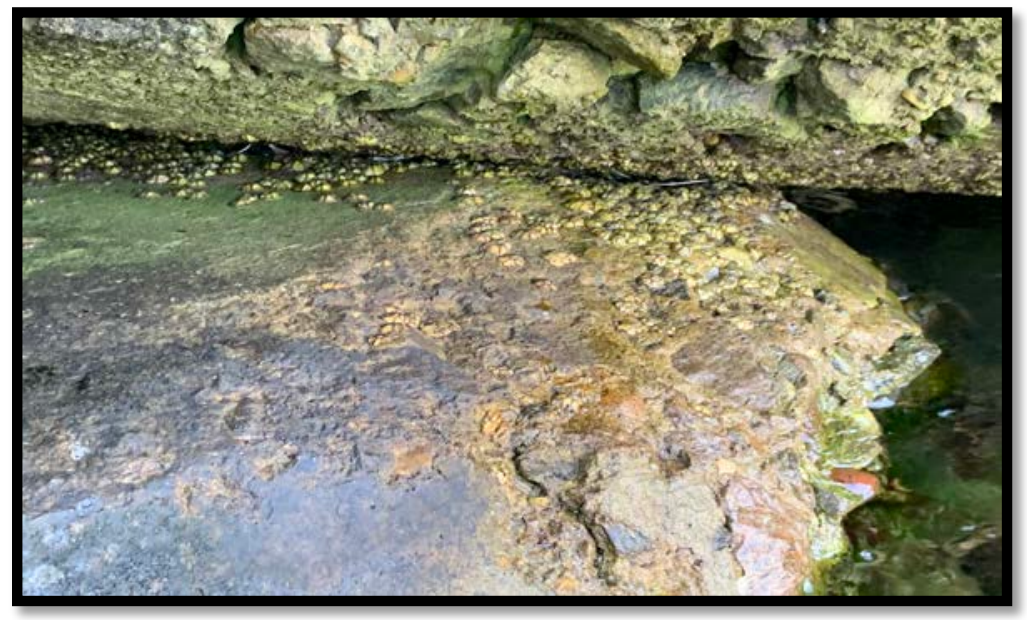

Fig. 1. Microeuraphia depressa population on hard substrata sides In Constanta harbour (Photo: A. Filimon)

Individuals from hard substrata sides had opaque shell walls (Fig. 2) but those from undersides had semitransparent shells. Semitransparent shells are characteristic of animals growing under stones (Achituv \& Safriel, 1980). The carino-rostral diameter ranges from 4 to $15 \mathrm{~mm}$.

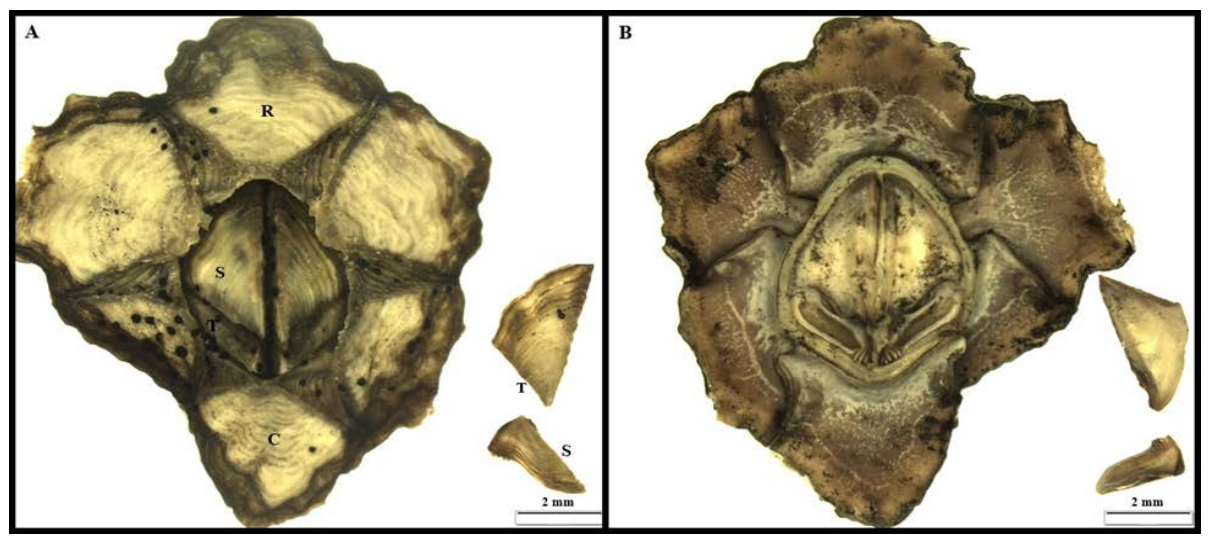

Fig. 2. Microeuraphia depressa specimens found in Constanta harbour (Romania). (A) apical view of shell; (B) internal view; (C) Carina; (R) Rostrum; (T) Tergum; (S) Scutum. (Photo: A. Filimon)

This can be considered a clear evidence that a monitoring program under Marine Strategy Framework Directive (MSFD) (EC, 2017), should 
target the Romanian harbours, too. A special effort must be focused on Constanta harbour which connects the Black Sea with the North Sea through the Rhine-Main-Danube Canal.

\section{CONCLUSIONS}

Acorn barnacle $M$. depressa was found in Constanta harbour, Romania. M. depressa could be historicaly present at the Romanian littoral and misidentified as $C$. stellatus. In this case, this would be the first correct taxonomical record of $M$. depressa in Romania. A monitoring program in Romanian harbours under MSFD, shall be implemented.

Acknowledgement. The authors wish to express their gratitude to Dr. Valentina Todorova, for the scientific advice and to Dr. Francis Kerckhof, for confirmation of taxonomical identification

\section{REFERENCES}

Achituv Y., Safriel U. N. (1980), Euraphia depressa (Poli) (Crustacea, Cirripedia), a recent Mediterranean colonizer of the Suez Canal. Bulletin of Marine Science, 30 (3): 724-726.

Antipa G. (1941), Black Sea. Vol. I Oceanography, Bionomy and General Biology of the Black Sea, Publicatiunile Fondului Vasile Adamachi, 10: 1-313 (in Romanian)

Bacescu M. C., Müller, G. I., Gomoiu M. T. (1971), Marine Ecology. Vol. 4. Benthic Ecological Research in the Black Sea; qualitative, quantitative and comparative analysis of Pontic benthic fauna. Romanian Academy, Bucuresti, Romania, 1-357. (in Romanian)

Borcea I. (1931), Nouvelles contributions à l'étude de la faune bentonique dans la Mer Noire, près du littoral roumain. Ann. Sci. Univ. Jassy, 16: 655-750 (in French).

Borcea I. (1937), Les résultats de l'expédition de recherches dans la Mer Noire entre les 28 Août et 1 Septembre 1935. Ann. Sci. Univ. Jassy, 23: 1-26.

Darwin C. (1854), A Monograph of the Subclass Cirripedia with figures of all the species. The Balanidae, the Verrucidae, etc. Ray Society, London, 1684.

European Commission (EC), (2017), Commission Decision (EU) 2017/848 of 17 May 2017 laying down criteria and methodological standards on good environmental status of marine waters and specifications and standardized methods for monitoring and assessment, and repealing Decision 2010/477/EU, Official Journal of the European Union L, 125: 43-74.

Igić L. (2007), Cirripedia of Adriatic. Studia Marina, 24: 1-168. 
Kensler C.B., Bhatnagar K.M., Crisp D.J. (1965), Distribution and ecological variation of Chthamalus species in the Mediterranean area. Vie Milieu (sér B), 16: 271-294.

Linetskii B., Son M. O., Koshelev A. V. (2020), Contribution to the knowledge on supralittoral macroinvertebrates of the northwestern Black Sea. Ecologica Montenegrina, 34: 8-19.

Newman W.A, Ross A. (1976), Revision of the balanomorph. barnacles: including a catalog of the species. Mem San Diego Soc Nat Hist, 9:1108.

Poli G. S. (1791), Testacea Utriusque Siciliae Eorumque Historia et Anatome. Tomus primus \& Tomus secundus.

Poltarukha O. P. (2006), Identification atlas of the Superfamily Chthamaloidea (Cirripedia Thoracica) in the world ocean. KMK Scientific Press Ltd, Moscow, 1-198.

Preda C., Memedemin D., Skolka M.,Cogălniceanu D. (2012), Early detection of potentially invasive invertebrate species in Mytilus galloprovincialis Lamarck, 1819 dominated communities in harbours. Helgoland marine research, 66 (4): 545-556.

Ranzani, G. (1818), Osservazione sui Balanidae. Opuscoli Scientifici, 2: 6393.

Relini G. (1980), Guide per il riconoscimento delle species animali delle acque lagunari e costiere italiane. 2. Cirripedi Toracici. Consiglio Nazionale delle Ricerche AQ, 1:1-122.

Southward A. J. (1964), On the European species of Chthamalus (Cirripedia). Crustaceana, 6 (4): 241-254.

Utinomi H. (1959), Cirripedia Thoracica from the western Mediterranean. Vie et Milieu, 10 (4): 400-404.

WoRMS, (2021), Microeuraphia depressa (Poli, 1791). Accessed at: http://marinespecies.org/aphia.php?p=taxdetails\&id=882468 on 202108-24. 